end of middle third of length narrowing to a much narrower blade which distad expands a little, somewhat clavately, the end being rounded, with no acute or spine-like process. Basal spine short and stout, at tip subconically narrowed, the apex narrowly rounded.

Length near $42 \mathrm{~mm}$. Width $10 \mathrm{~mm}$.

Locality. Glendale Hills, south of Nashville. April 21, 1917.

One male.

Hillsboro Hills, Nashville, April 22, 1917. One female apparently of this species.

Also "Beyond Glendale," Oct. 14, 1916. One male and an immature specimen. The male is not in full color, the brighter carinal and marginal markings being scarcely evident. The general color is dusky over a dull yellow background. A dark median longitudinal dorsal line shows posteriorly. It appears to be a recently moulted individual.

\title{
NOTES ON DIPTERA. ${ }^{1}$
}

By J. M. Aldorich.

(a) In studying the habits of the "salt-fly" of Great Salt Lake (Ephydra gracilis Pack.) in 1911, I noted that trains crossing the lake on the famous Southern Pacific cutoff west of Ogden raise a constant swarm of these flies for an hour, and many of the insects get into passenger trains in spite of efforts to keep them out by closing the windows. My report says (Jour. N. Y. Ent. Soc., xx, 84, 1912), "They become a nuisance . . . in the dining cars. I had no difficulty in finding some of the flies in the latter situation as far west as Reno, Nev., and I doubt not that they may be found after the cars reach Oakland."

I can now add that the species has established itself in San Francisco Bay. On July 10, 1917, in sweeping about several little saline pools close to the shore of the Bay next to Palo Alto, I captured 18 specimens, indicating that it is a common species 30 miles south of the Oakland mole. I had no opportunity to examine other portions of the Bay shore.

Prior to the running of trains across Great Salt Lake, which

${ }^{1}$ Published by permission of the Chief of the U. S. Bureau of Entomology, 
began in 1904, there was no such opportunity for the files to be carried, as the trains did not run close enough to the water.

That the species is not indigenous to San Francisco Bay is fairly well demonstrated by the following facts: (1) It was not in the Stanford University collection, which is rich in local Diptera, the accumulations of many years, and is only about $2 \frac{1}{2}$ miles from the place where I recently found the species; (2) It is not in the collection of the University of California, although a few years ago an advanced student, Burle R. Jones, made and published a special study of California Ephydridæ, for which he collected extensively about the Bay (Catalogue of the Ephydridæ, etc. Technical Bull., Cal. Agr. Exp. Station, 1908); (3) It is not in the collection of the California Academy of Sciences, nor was it in the old collection destroyed by fire in 1906, as I personally know from examination; (4) In 1905-6 I collected repeatedly along the Bay near Palo Alto, and visited the same place again once in 1911, without finding the species.

As a matter of fact, up to the present report there have been only about half a dozen specimens of the species ever found away from Great Salt Lake; these are from Yuma and Salton Sea in the National Museum, one from Laguna, Cal., taken by C. F. Baker, and one from "S. Cal." which Jones made the type of Ephydra cinerea. The last two, which I have studied, are larger than the average but not larger than the largest specimens from Great Salt Lake, and the same is true of the 18 specimens I secured near Palo Alto last summer. This perhaps indicates that the extreme density of the water in Great Salt Lake exercises a dwarfing influence upon the species.

(b) When Van der Wulp described Charadrella macrosoma new genus and species, from Northern Yucatan (Biologia Cent.-Amer., Dipt., ii, 341, 1896), he added the following note:

"As the fourth vein is not curved, but runs directly to the tip of the wing, this genus is included here among the Anthomyinæ; on account, however, of the presence of a perpendicular row of macrochaetæ on the hypopleuræ, before the halteres, it would not belong to the Anthomyinæ in the sense of Girschner's system of the Muscidæ Calypteræ."

An Anthomyid with hypopleural bristles would be anomalous indeed, and I have long desired to see the species. The desire was 
gratified last January, when I found it correctly identified in Professor Hine's collection from Guatemala and British Guiana. The specimens agree with Van der Wulp's description throughout, except for one thing:- there is not the slightest trace of the row of hypopleural bristles. The genus has so many strong characters that misidentification seems impossible; the only other explanation of the discrepancy is that Van der Wulp saw the bristles on some other fly and got it confused with this species, and this I think is what happened.

Since Charadrella has a number of unusual features, and does not fit well in any of the subfamilies recognized by Malloch in his recent tabulation (Canad. Ent., Dec., 1917, 406), I add the following mostly chaetotactic characters taken from one of Professor Hine's males:

Head: front one-fourth the head-width at vertex, widening forward very gradually; frontals in a single row, about 10, the lowest just at the antennal insertion; ocellars broadly diverging, slightly proclinate; no cruciate bristles; verticals as usual but not strong; vibrissæ large, just at the lower edge of head, above them a patch of small black hairs extending more than halfway to root of antennæ and nearly halfway to the eye; infra-orbital cilia (setæ) pale.

Thorax: ps de 3 (from the spacing 4 will probably also occur), ant dc 2 , hum 4, posthum 1, prs 1, npl 2, intal 2, supal 3 (of which the prealar is less than half as long as the next), postal 2, ant acr 0 , post acr 1 (prsc), stpl 3 (the anterior small, posterior 2 close together vertically), mesopleura with 3 at lower front corner and a row of 6 behind, sternopleura and mesopleura with upright rather long pale hairs which also cover the pteropleura, hypopleura bare; scutellum with two long pairs, marginal and apical, and several small submarginal, the disk very hairy; both spiracles very large; hind calypter much exceeding front one; scutellum bare below.

Abdomen: first and second segments without bristles above, third with 4 marginals, fourth with 6 marginals and a discal pair so far apart that they stand almost at the edge; sternites $2-5$ with a few bristles; 2-4 separated from the tergites by a wide membrane; genitalia small.

Wing: third and fourth veins strongly divergent toward tip, 
the third sinuous, ending a little before apex, fourth very slightly turned forward near tip, less than third; no setæ on any veins, no costal spine; sixth vein does not reach margin, seventh parallel with it.

Legs: tibiæ almost without bristles, hind basitarsus not with spine below.

(c) In the Carnegie Museum are three flies which were probably captured farther north than any others on record. They were taken by J. W. Goodsell, surgeon of the Peary Expedition, and are labeled, " 82 degrees north latitude, on the beach at the northeastern extremity of L. Hazen, in the interior of Grant Land. June 7, 1908." This would be about 550 miles from the pole. One of the specimens is Fucellia pictipennis Beck., a species described from Greenland and taken since in the Arctic by the Canadian Arctic Expedition. The other two specimens belong to Phormia terronovee Desv., described from Newfoundland and again from Greenland, a circumpolar species which is common in the mountains of the western states and occurs rarely in lower altitudes (Indiana, New Jersey).

(d) Two or three years ago Professor Johannsen inquired of me if I had any males of Lonchoptera. On going over my material, I was surprised to find but two males; - one from Colorado, taken by C. F. Baker, the other from the Parry Sound region of Ontario, taken by H. A. Parish. My attention being thus directed to the rarity of males, I followed up the matter during my sweeping work in the summer of 1916, noting in each sweeping the number and sex of the Lonchopteras. At the end of the season I had counted 2,652 specimens, all females, not a single male appearing. Most of these were taken in northern Indiana, but many were from other parts of the United States, and a few from Ontario.

In this connection should be mentioned Mr. Lundbeck's treatise on Lonchoptera in his beautiful series called Diptera Danica, v, 1-18, 1916. He recognizes in Denmark three species,-tristis, lutea and furcata. He says nothing about any rarity of males in the first two, but in furcata he says he has not seen the male, and only about six are known in collections, while the female is common. This is a parallel case, if in fact we do not have the same species, as I believe we do.

(e) The common leaf-miner Agromyza pusilla has many host- 
plants; I have reared it from mines in leaves of the common milkweed, Asclepias syriaca, and have found apparently the same maggot in leaves of horsemint, Monarda punctata. These two plants seem rather unfavorable for the purpose, on account in the one case of the abundant milk, and in the other the fiery taste. Yet on closer investigation neither of these qualities hinders the miner. In the case of milkweed, the miner feeds in the palisade tissue and does not touch the laticiferous system lying lower down in the leaf. If it should by accident cut into these vessels, it would no doubt be drowned in the outflow of milk, but apparently this does not happen. It enters and departs by the upper surface.

In the case of Monarda the explanation is not so easy to get at. The hot taste comes from the essential oil, of course, and it seemed that this must occur in some tissues not attacked by the maggot; but $I$ asked several botanists in vain as to the location of the oil deposits. At length Dr. W. N. Steil, of the botanical department of the University of Wisconsin, told me that the identical point had been investigated in that department; he looked it up and kindly wrote me that the oil was found to occur only in the trichomes in Monarda. These being entirely superficial organs, of course the maggot does not eat them.

No special instinct would seem to be necessary in either of these cases.

(f) In Melander and Spuler's paper on Sepsidæ (Bull. 143, Wash. Agr. Exp. Station) they mention on page 44 my capture of Themira putris L. attending plant-lice on cottonwood, and the same record occurs in my Catalogue of Diptera, page 619. As a slight contribution to the history of the spread of the species I will add that this occurred four miles north of Brookings, S. D., on Aug. 9,1891 , ten years before the first record of the occurrence of the species in North America, which record was by G. Chagnon, in The Entomological Student, ii, 13, 1901; his locality was Montreal. My specimens attending plant-lice were on a tree a few feet from a privy, and this was probably the source of the flies. I still recall my exultation when I succeeded in tracing the species in Schiner's Fauna Austriaca, and found it new to North America.

(g) Chrysomyza demandata Fabr. was first reported from North America by C. W. Johnson in Ent. News, xi, 609, 1900; localities were Philadelphia and Riverton, N. J. The year of capture is 
given by Knab as 1897 in Science for January 14, 1916,- presumably he took it from specimens sent by Johnson to Coquillett for determination. The earliest date on specimens in the collections of the Illinois State Laboratory of Natural History is August, 1908, and Tucker reported it from Kansas in the same year (Kans. Acad. Sci., xxii, 278, 1908), but probably collected it earlier. In the Pacific Northwest, I collected a specimen at Pendleton, Ore., on May 19, 1907; Mr. Wm. M. Mann secured two at Wawawai, Wash., on Aug. 30, 1908; and it was common on carrot flowers at Moscow, Idaho, on Sept. 4, 1908. It was in Arizona in 1910 (C. N. Ainslie, Proc. Ent. Soc. Wash., xiii, 118). These items may be of service in tracing the spread of the species.

(h) I am indebted to W. H. Dall, of the National Museum, for further information about the Psilopus of Poli, 1795, which was long supposed to preoccupy the same name as applied to a genus in the Dolichopodidæ. Poli's large work, "Testacea utriusque Siciliæ," is unique as a taxonomic effort, in that the writer used a complete double set of names, - a genus and species for each kind of shell, and an entirely different genus and species for the soft parts of the same mollusc. Thus the system is tetranomial rather than binomial, and Dr. Dall informs me that it is considered by taxonomists in Mollusca to be entirely outside of nomenclature; he added in reply to my question that he was not aware of any controversy whatever on the point. This is the same point of view expressed by Sherborn in Index Animalium, noted by me in Canadian Entomologist, 1910, 100. Since it seems that Poli's work is the same nomenclaturally as if it had never been written, there can be no objection to the use of Psilopus by Meigen in 1824.

In this connection it may be well to add that the distinctions upon which I based Gnamptopsilopus 1893, and recognized Agonosoma as distinct from Psilopodinus in my Catalogue of 1905, break down entirely in the oriental region; so I would not include all in Psilopus. 

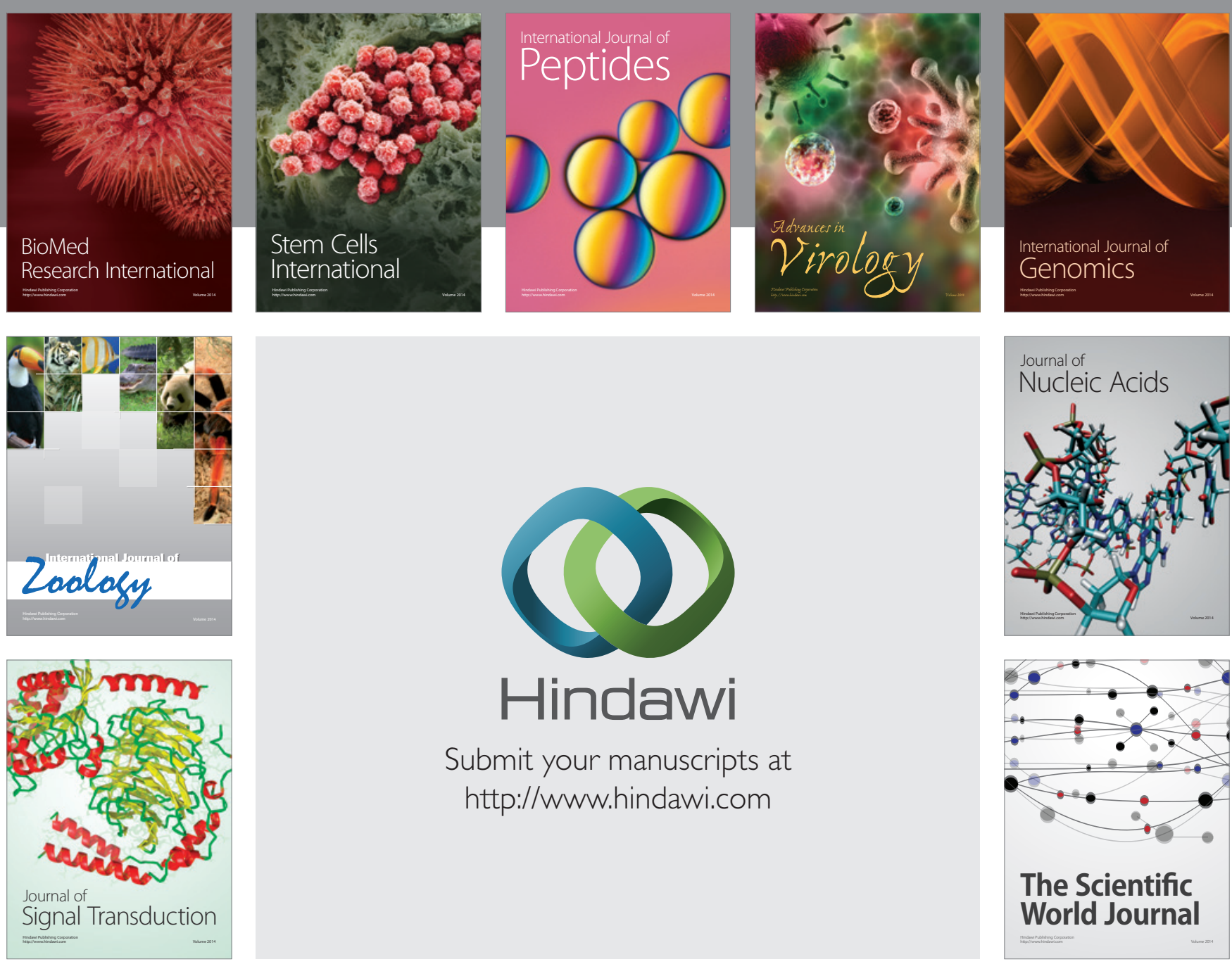

Submit your manuscripts at

http://www.hindawi.com
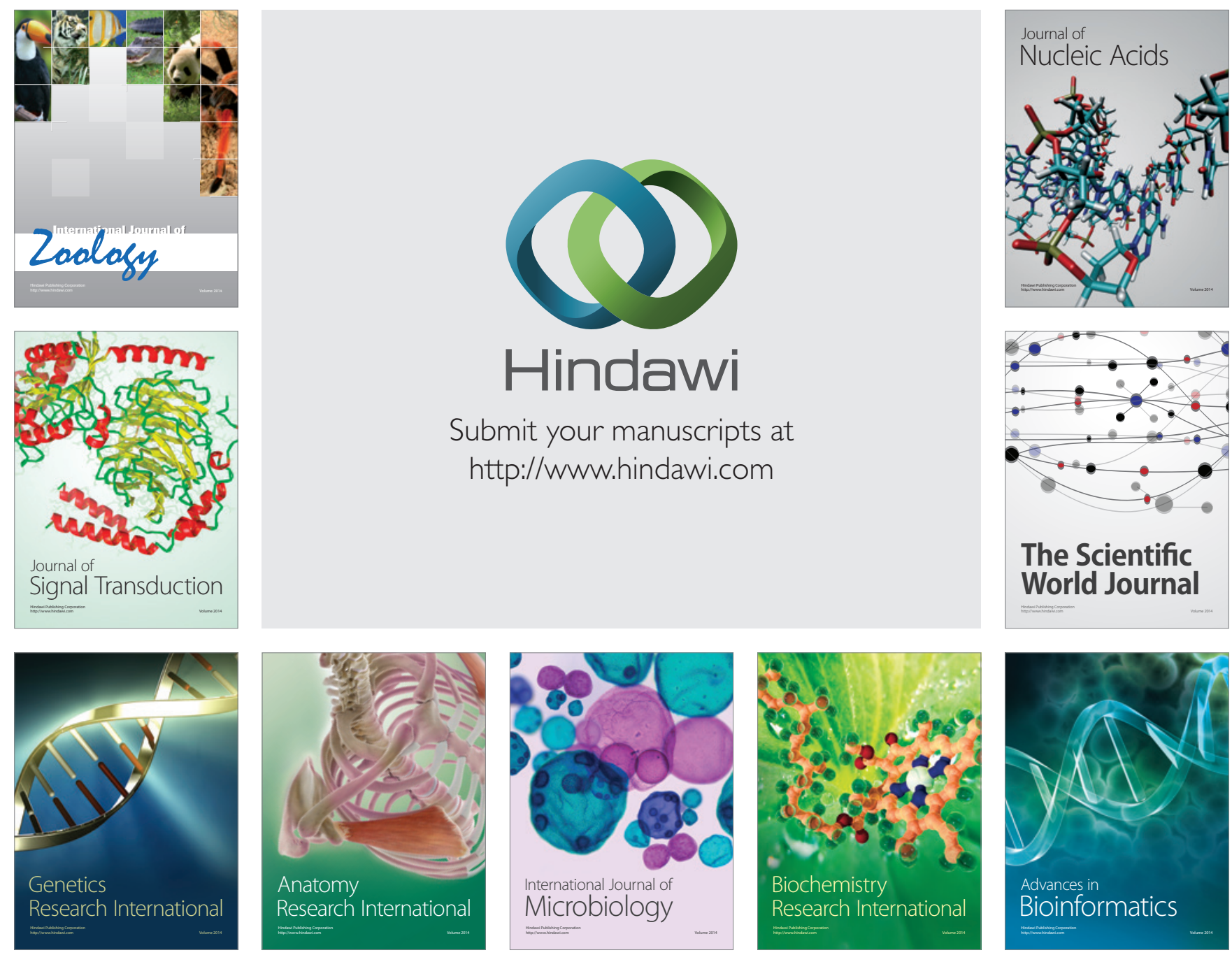

The Scientific World Journal
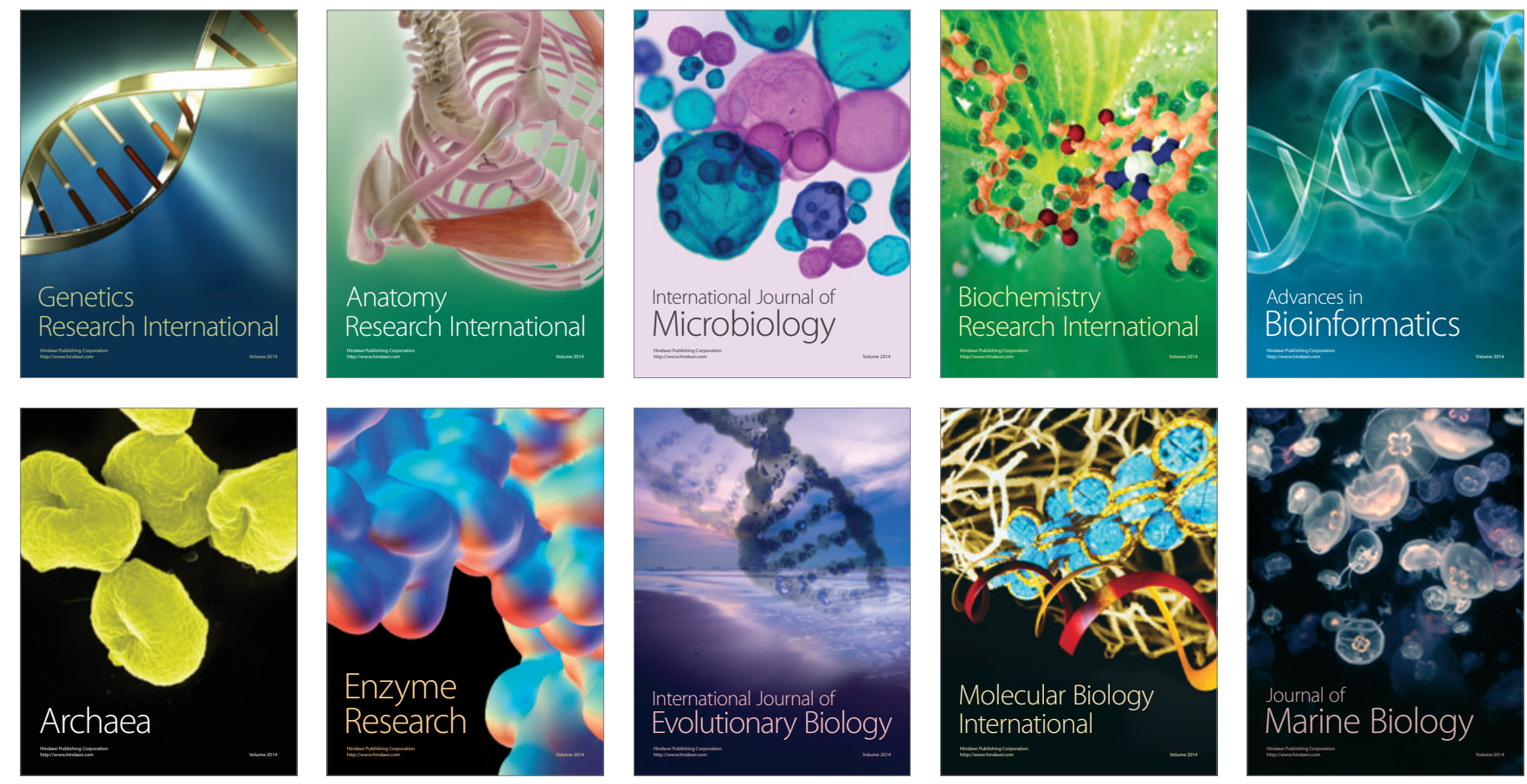